\title{
5W+1H Rekrutmen, Seleksi, Penempatan Pendidik dan Tenaga Kependidikan
}

\author{
Rony Sandra Yofa Zebua* \\ *Magister Pendidikan Islam, Universitas Islam Bandung \\ Published Since: 28 October 2020 \\ Published in: OSF Preprints \\ Edition: $1^{\text {st }}$ \\ Essay Document \\ DOI: $10.31219 /$ osf.io/ng3ck
}

\section{A. PENDAHULUAN}

Rekrutmen, seleksi dan penempatan pendidik dan tenaga kependidikan merupakan rangkaian proses yang berkesinambungan dalam pengelolaan sebuah lembaga pendidikan. Manajemen sekolah secara periodik memiliki tanggung jawab untuk melakukan kegiatannya berdasarkan perencanaan dan analisis kebutuhan serta analisis pekerjaan. Selain itu, pelaksanaan aktivitas ini ditujukan untuk mempertahankan keberlangsungan kegiatan pendidikan dan meningkatkan pelayanan lembaga pendidikan tersebut.

\section{B. REKRUTMEN PENDIDIK DAN TENAGA KEPENDIDIKAN}

Rekrutmen merupakan rangkaian kegiatan atau proses yang digunakan secara legal untuk memperoleh individu yang berkualitas pada ruang dan waktu tertentu, sehingga lembaga dan individu dapat memilih satu sama lain minat jangka pendek dan jangka panjang (Danumiharja, 2014, h. 125). Menurut Schuler dan Jackson (1997 seperti dikutip dalam Tama \& Hardiningtyas, 2017, h. 111), rekrutmen meliputi usaha mencari sejumlah calon pekerja yang memenuhi syarat dalam jumlah tertentu. Sehingga rekruitmen dapat diartikan sebagai proses mencari, menemukan, mengajak dan menetapkan sejumlah orang dari dalam maupun dari luar perusahaan sebagai calon tenaga kerja dengan karakteristik 
tertentu seperti yang telah ditetapkan dalam perencanaan Sumber Daya Manusia atau SDM dan analisis pekerjaan (Tama \& Hardiningtyas, 2017, h. 111).

Dalam bahasa yang lebih sederhana, rekrutmen adalah proses menarik minat dan mengumpulkan orang-orang yang sesuai dengan rencana dan kriteria SDM untuk menempati suatu tanggung jawab tertentu (Soetjipto, 2008, h. 144). Jadi rekrutmen bisa juga dianalogikan sebagai ajang pencarian bakat untuk sebuah posisi tertentu (Priansa \& Suwatno, 2013, h. 63 seperti dikutip dalam Rahman, Ardiansyah \& Marwazi, 2015, h. 27). Adapun proses rekrutmen dimulai sejak mencari para pelamar dan diakhiri dengan diterimanya surat-surat lamaran (Sirait, 2006, h. 57).

Dalam lingkungan pendidikan, rekrutmen pendidik dan tenaga kependidikan adalah aktivitas dan proses mencari dan mengadakan calon pendidik dan tenaga kependidikan yang berkualitas dan potensial secara legal sehingga sekolah dapat menyeleksi orang-orang yang paling sesuai bagi kebutuhan kerja yang ada (Danumiharja, 2014, h. 125). Rekrumen dalam lingkungan pendidikan juga harus memperhatikan dan mempertimbangkan adab dan akhlak dari SDM yang ada, karena lembaga pendidikan bukan hanya transfer ilmu namun juga transfer karakter (Zebua dkk., 2020, h. 123).

Rekrutmen pendidik dan tenaga kependidikan dilakukan dapat dilakukan secara langsung oleh pemangku kepentingan di sekolah ataupun melalui bantuan pihak ketiga atau agensi penyalur pencari kerja (Danumiharja, 2014, h. 131). Rekrutmen melibatkan pelamar dari sumber internal maupun eksternal yang berminat dan memiliki kriteria yang diharapkan oleh pihak sekolah (Tama \& Hardiningtyas, 2017, h. 111-112; Soetjipto, 2008, h. 144; Hariandja, 2002, h. 123). Sumber internal dalam rekrutmen meliputi para pendidik dan tenaga kependidikan sebelumnya yang berminat untuk di promosikan atau pindah penugasan, rekan-rekan dari pendidik dan tenaga kependidikan atau dari pengelola sekolah yang direkomendasikan, pencari kerja atau pelamar yang sebelumnya pernah mengikuti proses rekrutmen dan seleksi sebelumnya (Danumiharja, 2014, h. 129). Sedangkan sumber eksternal dalam rekrutmen 
adalah pelamar umum yang tidak ada kaitannya dengan sumber daya manusia yang ada di sekolah selama ini (Danumiharja, 2014, h. 131).

Rekrutmen pendidik dan tenaga kependidikan dilakukan berdasarkan analisa kebutuhan dari analisis pekerjaan yang telah dilakukan pada tahap sebelumnya dan kesanggupan sekolah berdasarkan analisis keuangannya. Hasil yang diperoleh dari proses rekrutmen adalah sejumlah calon pendidik dan tenaga kependidikan yang akan diikut sertakan dalam proses seleksi (Tama \& Hardiningtyas, 2017, h. 111).

\section{B.1. Tujuan dan Pentingnya Rekrutmen}

Tujuan umum rekrutmen adalah untuk menyiapkan sejumlah calon pendidik dan tenaga kependidikan yang berkualitas dan potensial bagi sekolah (Danumiharja, 2014, h. 127). Adapun menurut Simamora (1997 seperti dikutip dalam Tama \& Hardiningtyas, 2017, h. 111), rekrutmen bertujuan untuk:

1. Memikat sebagian pencari kerja sehingga sekolah akan mempunyai kesempatan yang lebih besar untuk memilih diantara mereka yang dianggap memenuhi kriteria dan standar yang telah ditetapkan.

2. Mengikat secara legal sehingga SDM pendidik dan tenaga kependidikan sebagai pelaksana kegiatan di sekolah tetap terjaga.

3. Meningkatkan reputasi umum sekolah dengan kesan-kesan positif yang diperoleh oleh para pencari kerja selama mengikuti proses rekrutmen.

Sedangkan tujuan spesifik rekrutmen, menurut Danumiharja (2014, h. 127-128) diantaranya adalah sebagai berikut:

1. Untuk menetapkan kebutuhan rekrutmen sekolah masa sekarang dan masa yang akan datang, hal ini kaitannya dengan perencanaan SDM dan analisis pekerjaan.

2. Untuk mendapatkan sejumlah calon pendidik dan tenaga kependidikan dengan biaya minimum. 
3. Untuk membantu meningkatkan angka keberhasilan dari proses seleksi dengan memberikan informasi yang jelas tentang kriteria yang dibutuhkan.

4. Untuk membantu menurunkan angka kemungkinan mundur terhadap pendidik dan tenaga kependidikan yang telah direkrut dan diseleksi.

5. Untuk memenuhi tanggung jawab sekolah terkait ketentuan komposisi pendidik dan tenaga kependidikan.

6. Sebagai identifikasi awal dalam menyiapkan SDM potensial yang akan menjadi calon pendidik dan tenaga kependidikan yang sesuai.

7. Sebagai upaya dalam meningkatkan keefektifan sekolah dan individu dalam jangka pendek dan panjang.

8. Untuk mengevaluasi keefektifan teknik dan pencarian rekrutmen yang beragam dari semua jenis pendidik dan tenaga kependidikan.

\section{B.2. Metode Rekrutmen}

Proses rekrutmen dimulai dari menyebarkan informasi kebutuhan SDM di sekolah, kemudian pengisian dan pengiriman formulir lamaran kerja oleh pelamar kerja. Apabila formulir lamaran kerja bersifat online, maka sebelumnya pengelola sekolah atau tim rekrutmen yang ditunjuk terlebih dahulu menyiapkan aplikasi online yang dibutuhkan. Penggunaan formulir ini bertujuan untuk memperoleh informasi awal dari pelamar kerja. Umumnya formulir lamaran kerja berisikan data personal atau tentang diri pelamar, pendidikan dan keterampilan, pengalaman kerja, kegiatan sosial, minat atau hobi, referensi dan tanda tangan pelamar (Sirait, 2006, h. 62). Selanjutnya tim rekrutmen mengumpulkan lamaran kerja dan memeriksa kelengkapan yang dibutuhkan.

Prioritas perekrutan pendidik dan tenaga kependidikan dititik beratkan pada orientasi manajemen pendidik dan tenaga kependidikan berdasarkan pertimbangan dan kebijakan yang telah direncanakan (Danumiharja, 2014, h. 128). Adapun metode-metode yang digunakan dalam rekrutmen pendidik dan tenaga kependidikan adalah metode internal dan metode eksternal (Tama \& 
Hardiningtyas, 2017, h. 111; Schuler \& Jackson, 2006 seperti dikutip dalam Mardiah, 2016, h. 226). Metode internal ditujukan untuk mendapatkan sumber perekrutan dari internal sekolah, sedangkan metode eksternal ditujukan untuk mendapatkan SDM sumber perekrutan dari eksternal sekolah. Metode internal dapat dilakukan melalui pengumuman pada papan pengumuman di sekolah, dari mulut ke mulut, surat personalia sekolah, daftar promosi berdasarkan kinerja, skill atau senioritas, rating potensial (Danumiharja, 2014, h. 129-130) dan penarikan kembali atau rehire (Schuler \& Jackson, 2006 seperti dikutip dalam Mardiah, 2016, h. 226).

Metode eksternal dapat dilakukan melalui media masa elektronik maupun cetak umum, seperti informasi atau iklan di surat kabar, radio, televisi (Danumiharja, 2014, h. 133-134). Selain itu, metode eksternal dapat dilakukan dengan menggunakan jasa pihak ketiga atau bekerjasama seperti agensi penyalur pencari kerja atau agen tenaga kerja, lembaga-lembaga pendidikan, lembagalembaga pelatihan, dan lain-lain (Hariandja, 2002, h. 123). Rekrutmen dengan metode eksternal juga dapat dilakukan melalui proses akuisisi atau merger sebuah lembaga pendidikan (Danumiharja, 2014, h. 134) dan dengan cara headhunters atau mencuri pegawai dari organisasi lain dengan cara membujuknya (Sirait, 2006, h. 61). Kegiatan dalam metode eksternal dapat dilakukan dengan pola walk-ins maupun write-ins (Sirait, 2006, h. 61; Hariandja, 2002, h. 123) dan open house atau mengundang sekelompok orang dan mempresentasikan terkait kebutuhan organisasi atau sekolah (Sirait, 2006, h. 60).

Berdasarkan uraian diatas, maka cakupan " $5 \mathrm{~W}+1 \mathrm{H}$ " dari rekrutmen pendidik dan tenaga kependidikan secara ringkas terdapat pada Tabel 1.

Tabel 1. Ringkasan Rekrutmen Pendidik dan Tenaga Kependidikan

\begin{tabular}{|c|l|}
\hline Cakupan & \multicolumn{1}{|c|}{ Spesifikasi } \\
\hline What & $\begin{array}{l}\text { Proses mencari, menemukan, mengajak, mengumpulkan dan } \\
\text { mengadakan calon pendidik dan tenaga kependidikan yang potensial } \\
\text { dan sesuai karakteristik atau standar yang diharapkan }\end{array}$ \\
\hline
\end{tabular}




\begin{tabular}{|c|l|}
\hline Who & $\begin{array}{l}\text { Pengelola sekolah atau pemangku kepentingan sekolah sebagai } \\
\text { penyelenggara. Atau pihak ketiga yang didelegasikan oleh } \\
\text { pengelola sekolah. } \\
\text { Pelamar dari sumber internal atau sumber eksternal yang } \\
\text { memiliki kriteria dan potensi yang diharapkan sebagai pihak yang } \\
\text { terlibat dalam perekrutan }\end{array}$ \\
\hline When & $\begin{array}{l}\text { Sesuai dengan kebutuhan sekolah dan kesanggupan keuangan } \\
\text { sekolah }\end{array}$ \\
\hline Where & $\begin{array}{l}\text { Di lingkungan sekolah atau di lingkungan pihak ketiga yang } \\
\text { digunakan oleh sekolah sebagai pihak ketiga dalam rekrutmen }\end{array}$ \\
\hline Why & $\begin{array}{l}\text { Untuk mengumpulkan dan menyiapkan sejumlah calon tenaga } \\
\text { pendidik dan kependidikan yang berkualitas dan potensial bagi } \\
\text { sekolah }\end{array}$ \\
\hline How & \begin{tabular}{l} 
Dengan metode internal dan eksternal \\
\hline
\end{tabular} \\
\hline
\end{tabular}

\section{SELEKSI PENDIDIK DAN TENAGA KEPENDIDIKAN}

Proses seleksi merupakan kelanjutan dari proses rekrutmen yang menghasilkan sekelompok pelamar yang memiliki potensi dan siap untuk diseleksi (Sirait, 2006, h. 57). Sehingga proses seleksi tidak dapat dipisahkan dengan proses rekrutmen (Hermino, 2013, h. 101).

Seleksi adalah proses untuk memilih dan memutuskan sumber daya manusia atau SDM yang tepat dari sekumpulan SDM yang telah dikumpulkan melalui proses perekrutan untuk bekerja atau bergabung dalam suatu organisasi atau perusahaan (Hariandja, 2002, h. 126). Menurut Sukamti (1989, h. 153 seperti dikutip dalam Hermino, 2013, 103), seleksi didefinisikan sebagai suatu proses penetapan pelamar yang direkrut melalui pertimbangan persyaratanpersyaratan untuk dapat diterima dalam melakukan pekerjaan dengan baik.

Dalam lingkungan pendidikan, seleksi adalah kegiatan untuk memilih dan menentukan pendidik dan tenaga kependidikan yang memenuhi kriteria dan harapan yang telah ditetapkan oleh sekolah, serta memprediksi kemungkinan keberhasilan atau kegagalan individu dari SDM pendidik dan tenaga kependidikan yang akan dipilih tersebut (Danumiharja, 2014, h. 137-138). 


\section{C.1. Kriteria Dasar Seleksi}

Agar seleksi pendidik dan tenaga kependidikan dilakukan secara efektif dan mencapai sasaran yang diharapkan, menurut Danumiharja (2014, h. 139141), seharusnya mempertimbangkan beberapa prinsip dasar yaitu:

1. Rasional, yaitu metode dan prosedur yang ditempuh dapat diterima akal sehat dan tidak terkesan dibuat-buat yang menyulitkan peserta seleksi.

2. Ilmiah, yaitu sesuai dengan prosedur dan tahapan ilmiah. Tujuannya adalah untuk memperoleh konklusi ilmiah berdasarkan postulat dan prasuposisi ilmiah tertentu

3. Objektif, yaitu proses seleksi berpihak pada kenyataan yang ada dan melepaskan subjektifitas terhadap para peserta seleksi

Kemudian menurut Danumiharja (2014), kriteria dasar seleksi pendidik dan yang berdaya guna dan profesional minimal memenuhi syarat sebagai berikut:

1. Berpedoman pada analisis pendidik dan tenaga kependidikan dan rencana perekrutan pendidik dan tenaga kependidikan. Sehingga penentuan dan pemilihan calon pendidik dan tenaga kependidikan berdasarkan uraian dan klasifikasi yang telah ditetapkan sebelumnya.

2. Efisien dan efektif, yaitu dengan menentukan atau memilih yang memiliki kecakapan secara maksimal dan diperkirakan mampu memenuhi harapan jangka pendek dan jangka panjang. Selain itu, pelaksanaan kegiatan seleksi juga harus sesuai dengan alokasi waktu dan rencana yang telah ditetapkan.

3. Memperhatikan peraturan dan ketentuan yang berlaku, artinya pelaksanaan kegiatan seleksi tidak boleh melanggar peraturan dan ketentuan yang berlaku baik yang dikeluarkan sekolah maupun pemerintah. 
4. Dilakukan secara objektif dan jujur, yaitu menekankan pertimbangan rasional daripada perasaan dan melepaskan pengaruh faktor subjektif seperi ras, suku, keluarga, teman, dan sejenisnya.

5. Dilakukan dengan profesional

\section{C.2. Penentuan Proses Seleksi}

Menurut Sukamti (1989, h. 164 seperti dikutip dalam Hermino, 2013, h. 110-111), ada empat standar yang dapat digunakan organisasi dalam proses seleksi, yaitu:

1. Relevansi, yaitu sejauh mana alat seleksi dapat mencerminkan sampel yang representatif dari pekerjaan. Sehingga alat seleksi harus sesuai dengan analisis pekerjaan yang telah ditetapkan.

2. Reliabilitas, yaitu sejauh mana alat seleksi memberikan hasil yang sama apabila dipakai dalam waktu yang tidak sama atau oleh orang yang berbeda. Sehingga jika seseorang di tes lebih dari satu kali dengan alat tes yang sama, maka hasilnya harus tetap sama.

3. Validitas, yaitu adanya hubungan statis atau valid antara skor-skor pada alat seleksi dengan kriteria atau ukuran performasi pekerjaan.

4. Faktor keadilan, yaitu alat seleksi harus dinilai dengan standar keadilan.

Setiap instansi atau sekolah memiliki model-model yang bervariasi dalam proses seleksinya, namun yang terpenting adalah bahwa setiap model memiliki langkah-langkah yang dilakukan secara sistematis agar hasil keseluruhan prosesnya dapat diandalkan (Hermino, 2013, h. 111). Menurut Danumiharja (2014, h. 144-146), ada beberapa strategi penting dalam menetapkan proses seleksi, yaitu:

1. Merumuskan dengan teliti peranan-peranan sehingga memiliki konsep yang jelas tentang standar dan kriteria yang diharapkan. 
2. Menetapkan standar seleksi, meliputi umur, kesehatan fisik, pendidikan, pengalaman bertugas, tujuan-tujuan, catatan perilaku, pengetahuan umum, keterampilan berkomunikasi, motivasi, minat, sikap dan nilai-nilai, kesehatan mental, kepantasan untuk bertugas, dan faktor lain yang mungkin ditetapkan secara khusus oleh pemerintah.

3. Strategi terkait jenis bukti yang dibutuhkan.

4. Adanya identifikasi calon secara jelas.

5. Mengumpulkan informasi yang diperlukan.

6. Adanya penilaian yang dilakukan secara seksama termasuk bukti-bukti terkait.

7. Prosedur mengusulkan calon yang terpilih.

\section{C.3. Tujuan Proses Seleksi}

Tujuan utama dari proses seleksi pendidik dan tenaga kependidikan adalah untuk memilih calon pendidik dan tenaga kependidikan yang sesuai dengan harapan sekolah dari para pelamar yang telah terkumpulkan dalam proses rekrutmen. Dalam proses ini, ada dua jenis informasi yang saling berhubungan timbal balik yaitu informasi tentang diri peserta seleksi dan informasi tentang sekolah seperti keadaan sekolah, kriteria SDM yang dibutuhkan sekolah, dan sebagainya (Danumiharja, 2014, h. 147). Dengan demikian seleksi tenaga kependidikan dilakukan untuk mendapatkan keyakinan tentang kecakapan, kepribadian, kebiasaan, data lain serta keterangan yang dianggap perlu untuk mendapatkan pendidik dan tenaga kependidikan yang berdaya guna dan berhasil guna sesuai dengan kriteria sekolah (Danumiharja, 2014, h. 147).

\section{C.4. Cara Dan Metode Seleksi}

Secara umum, cara dan metode yang dilakukan dalam proses seleksi meliputi seleksi persyaratan administrasi, pengetahuan umum, psikologi, wawancara, referensi (Danumiharja, 2014, h. 147), dan pemeriksaan kesehatan (Mardiah, 2016, h. 227). Selain itu, dalam lingkungan pendidikan juga ada 
menguji pengetahuan dan kemampuan cara mengelola kelas atau microteaching. Setiap institusi atau sekolah dapat mengkombinasikan dan mengembangkan tahapan-tahapan dalam proses seleksi berdasarkan pertimbangan masing-masing sekolah, sehingga terdapat berbagai variasi tahapan dalam proses seleksi.

Seleksi persyaratan administrasi bertujuan untuk memeriksa kelengkapan persyaratan administratif yang harus dipenuhi para pelamar (Danumiharja, 2014, h. 148). Seleksi pengetahuan umum yang dilakukan secara tertulis dengan soalsoal objektif, bertujuan untuk mengetahui kemampuan pengetahuan pelamar yang berhubungan dengan ruang linkup sekolh baik secara praktis maupun teoritis dan pengetahuan umum yang berhubungan dengan sistem ketatanegaraan Indonesia khususnya kebijakan terkait pendidikan (Danumiharja, 2014 , h. 149).

Adapun seleksi psikologi merupakan seleksi yang dilakukan untuk mengetahui keadaan individu dan kesanggupan calon pendidik dan tenaga kependidikan terhadap kemungkinan tanggung jawab pekerjaan yang akan diamanahi kepadanya (Danumiharja, 2014, h. 150). Secara umum, menurut menurut Ranupandowo dan Husnan (1986, h. 59 seperti dikutip dalam Hermino, 2013 , h. 114) dan diperkuat oleh Danumiharja (2014, h. 150-151) seleksi psikologi dapat digolongkan menjadi lima macam yaitu:

1. Achievement test atau tes hasil kerja, yaitu untuk mengukur atau mengetahui tingkat kemampuan bertugas yang dimiliki dan prediksi terhadap kecakapan dari calon pendidik dan tenaga kependidikan.

2. Aptitude test atau tes bakat/pembawaan, yaitu untuk mengukur bakat atau kemampuan yang mungkin telah dikembangkan atau masih terpendam dari calon pendidik dan tenaga kependidikan.

3. Intellegence test atau tes kecerdasan, yaitu untuk mengukur kemampuan berpikir calon pendidik dan tenaga kependidikan.

4. Interest test atau tes minat, yaitu untuk menentukan aktivitas yang paling menarik perhatian calon pendidik dan tenaga kependidikan. 
5. Personality test atau tes kepribadian, yaitu untuk mengukur atau menilai sifat kepribadian yang dimiliki calon pendidik dan tenaga kependidikan.

Seleksi wawancara merupakan proses tanya jawab atau komunikasi secara langsung melalui tatap muka antara delegasi penyeleksi dengan peserta seleksi yang bertujuan untuk mencari dan mendapatkan informasi mengenai motif, harapan, cita-cita, ciri-ciri khusus, dan sebagainya pada seorang peserta seleksi (Danumiharja, 2014, h. 152). Menurut Danumiharja (2014, h. 152-154), ada beberapa prinsip-prinsip dasar dalam wawancara, yaitu:

1. Performance, yaitu penilaian terhadap penampilan diri calon pendidik dan tenaga kependidikan.

2. Potential improvement, yaitu ciri potensi atau kemampuan dasar yang sekiranya dapat dikembangkan seperti intelegensi umum, kreatifitas, inisiatifm responsive, analisis.

3. Skill profile achievement, yaitu sejauh mana kecakapan yang dimiliki calon pendidik dan tenaga kependidikan.

4. Personal attitude, yaitu sifat dan sikap kejiwaan calon pendidik dan tenaga kependidikan.

5. Specific values, yaitu penilaian terhadap segala sesuatu yang menyangkut diri calon pendidik dan tenaga kependidikan.

Berdasarkan uraian diatas, maka cakupan " $5 \mathrm{~W}+1 \mathrm{H}$ " dari seleksi pendidik dan tenaga kependidikan secara ringkas terdapat pada Tabel 2.

Tabel 2. Ringkasan Seleksi Pendidik dan Tenaga Kependidikan

\begin{tabular}{|c|l|}
\hline Cakupan & \multicolumn{1}{|c|}{ Spesifikasi } \\
\hline What & $\begin{array}{l}\text { Proses untuk memilih dan menentukan pendidik dan tenaga } \\
\text { kependidikan yang memenuhi kriteria dan harapan yang telah } \\
\text { ditetapkan oleh sekolah, serta memprediksi kemungkinan } \\
\text { keberhasilan atau kegagalan individu dari SDM pendidik dan tenaga } \\
\text { kependidikan yang akan dipilih tersebut }\end{array}$ \\
\hline
\end{tabular}




\begin{tabular}{|c|c|}
\hline Who & $\begin{array}{l}\text { - Pengelola sekolah atau pemangku kepentingan sekolah sebagai } \\
\text { penyelenggara. Atau pihak ketiga yang didelegasikan oleh } \\
\text { pengelola sekolah. } \\
\text { - Pelamar yang memenuhi kriteria dan potensi yang diharapkan } \\
\text { sebagai pihak yang terlibat dalam seleksi }\end{array}$ \\
\hline When & Setelah proses rekrutmen \\
\hline Where & $\begin{array}{l}\text { Di lingkungan sekolah atau di lingkungan pihak ketiga yang } \\
\text { digunakan oleh sekolah sebagai pihak ketiga dalam rekrutmen }\end{array}$ \\
\hline Why & $\begin{array}{l}\text { Untuk memilih pendidik dan tenaga kependidikan yang sesuai } \\
\text { dengan harapan sekolah berdasarkan kesesuaian penilaian terhadap } \\
\text { kriteria yang dibutuhkan sekolah dan validitas data yang diberikan } \\
\text { pelamar }\end{array}$ \\
\hline How & $\begin{array}{l}\text { Seleksi persyaratan administrasi, menguji pengetahuan umum, } \\
\text { mengidentifikasi psikologi, wawancara, seleksi referensi, } \\
\text { pemeriksaan kesehatan, microteaching. }\end{array}$ \\
\hline
\end{tabular}

\section{PENEMPATAN PENDIDIK DAN TENAGA KEPENDIDIKAN}

Penempatan adalah pencocokan seseorang yang lolos seleksi atau sesuai kriteria promosi dengan posisi atau jabatan yang akan dipegangnya berdasarkan kebutuhan jabatan dan pengetahuan, keterampilan, kemampuan, preferensi, serta kepribadian karyawan tersebut (Hermino, 2013, h. 103-104). Penempatan juga didefinisikan sebagai proses menempatkan posisi seseorang ke posisi pekerjaaan yang tepat (Mathis \& Jackson, 2006, h. 262 seperti dikutip dalam Fadilah, 2013, h. 848).

Adapun penempatan pendidik dan tenaga kependidikan adalah proses pemberian tugas dan pekerjaan kepada calon pendidik dan tenaga kependidikan yang lulus seleksi berdasarkan ruang lingkup yang telah ditetapkan, serta mampu mempertanggung jawabkan segala resiko dan kemungkinan-kemungkinan yang terjadi atas tugas dan pekerjaan, wewenang, serta tanggung jawabnya (Siswanto, 2003 seperti dikutip dalam Mardiah, 2016, h. 227).

\section{D.1. Tujuan Proses Penempatan}


Tujuan utama proses penempatan adalah untuk menempatkan pendidik dan tenaga kependidikan sebagai unsur pelaksana kegiatan sekolah pada posisi yang sesuai dengan kemampuan, kecakapan, dan keahliannya (Sastrohadiwiryo, 2002, h. 38). Sehingga setiap individu memegang tanggung jawab yang sesuai dengan memiliki kualifikasi dan kompetensi (Zebua dkk., 2020, h. 123).

\section{D.2. Strategi Penempatan}

Strategi penempatan pendidik dan tenaga kependidikan yang lulus proses seleksi dilakukan dengan cara memperhatikan latar belakang ijazah, mengutamakan pengalaman kerja, serta penilaian dari proses seleksi pada sikap dan penampilan calon pendidik dan tenaga kependidikan berdasarkan analisis pekerjaan dan perencanaan SDM yang telah ditentukan sebelumnya (Rahmi \& Isnaya, 2017, h. 37). Ada beberapa faktor-faktor yang dipertimbangkan dalam proses penempatan, diantaranya menurut Sastrohadiwiryo (2002, h. 162) meliputi faktor latar belakang pendidikan, faktor kesehatan jasmani dan rohani, faktor pengalaman kerja, faktor umur sumber daya manusia, faktor jenis kelamin, faktor status perkawinan, faktor minat dan hobi.

Berdasarkan uraian diatas, maka cakupan " $5 \mathrm{~W}+1 \mathrm{H}$ " dari seleksi pendidik dan tenaga kependidikan secara ringkas terdapat pada Tabel 3.

Tabel 3. Ringkasan Penempatan Pendidik dan Tenaga Kependidikan

\begin{tabular}{|c|l|}
\hline Cakupan & \multicolumn{1}{|c|}{ Spesifikasi } \\
\hline What & $\begin{array}{l}\text { Proses pemberian tugas dan pekerjaan kepada calon pendidik dan } \\
\text { tenaga kependidikan yang lulus seleksi berdasarkan ruang lingkup } \\
\text { yang telah ditetapkan, serta mampu mempertanggung jawabkan } \\
\text { segala resiko dan kemungkinan-kemunginan yang terjadi atas tugas } \\
\text { dan pekerjaan, wewenang, serta tanggung jawabnya }\end{array}$ \\
\hline Who & $\begin{array}{l}\text { Pengelola sekolah atau pemangku kepentingan sekolah sebagai } \\
\text { penyelenggara, khususnya kepala sekolah. } \\
\text { Calon pendidik dan tenaga kependidikan yang lulus seleksi }\end{array}$ \\
\hline
\end{tabular}




\begin{tabular}{|c|l|}
\hline When & Setelah proses seleksi \\
\hline Where & Di lingkungan sekolah \\
\hline Why & $\begin{array}{l}\text { Untuk menempatkan pendidik dan tenaga kependidikan sebagai } \\
\text { unsur pelaksana kegiatan sekolah pada posisi yang sesuai dengan } \\
\text { kemampuan, kecakapan, dan keahliannya }\end{array}$ \\
\hline How & $\begin{array}{l}\text { Dilakukan dengan cara memperhatikan latar belakang ijazah, } \\
\text { mengutamakan pengalaman kerja, serta penilaian dari proses seleksi } \\
\text { pada sikap dan penampilan calon pendidik dan tenaga kependidikan } \\
\text { berdasarkan analisis pekerjaan dan perencanaan SDM yang telah } \\
\text { ditentukan sebelumnya }\end{array}$ \\
\hline
\end{tabular}

\section{E. KESIMPULAN}

Rekrutmen, seleksi dan penempatan pendidik dan tenaga kependidikan merupakan serangkaian proses yang berkesinambungan dalam usaha memperoleh SDM yang berkualitas dan sesuai dengan kebutuhan sekolah. Dimulai dari proses rekrutmen yang merupakan proses mencari, menemukan, mengajak, mengumpulkan dan mengadakan calon pendidik dan tenaga kependidikan yang potensial dan sesuai karakteristik atau standar yang diharapkan. Kemudian dilanjutkan dengan proses seleksi untuk menentukan calon yang layak dan potensial untuk dipilih dan telah melalui berbagai tahapan seleksi diantaranya seleksi persyaratan administrasi, menguji pengetahuan umum, mengidentifikasi psikologi, wawancara, seleksi referensi, pemeriksaan kesehatan, microteaching. Dan proses penempatan pendidik dan tenaga kependidikan adalah proses pemberian tugas dan pekerjaan kepada calon pendidik dan tenaga kependidikan yang lulus seleksi berdasarkan ruang lingkup yang telah ditetapkan, serta mampu mempertanggung jawabkan segala resiko dan kemungkinan-kemungkinan yang terjadi atas tugas dan pekerjaan, wewenang, serta tanggung jawabnya

\section{F. DAFTAR PUSTAKA}

Danumiharja, M. (2014). Profesi Tenaga Kependidikan. Sleman: Deepublish. 
Fadilah, A. N. (2013). Pengaruh Penempatan Pegawai Terhadap Kinerja (Studi Pada Pegawai Sekretariat Daerah Kabupaten Gresik). Jurnal Administrasi Publik, 1(5), 847-852.

Hariandja, M. T. E. (2002). Manajemen Sumber Daya Manusia. Jakarta: Grasindo.

Hermino, A. (2013). Asesmen Kebutuhan Organisasi Persekolahan: Tinjauan Perilaku Organisasi Menuju Comprehensive Multilevel Planning. Jakarta: Gramedia.

Mardiah, N. (2016). Rekrutmen, Seleksi Dan Penempatan Dalam Perspektif Islam. Jurnal MAQDIS: Jurnal Kajian Ekonomi Islam, 1(2), 223-235. https://doi.org/ 10.15548/maqdis.v1i2.47

Rahman, K. A., Ardiansyah \& Marwazi. (2015). Rekrutmen Tenaga Pendidik dalam Peningkatan Mutu Madrasah Aliyah Negeri Insan Cendekia Jambi. Jurnal NADWA: Jurnal Pendidikan Islam, 9(1), 23-38. https://doi.org/10.21580/nw.2015.9.1.518

Rahmi, S. \& Isnaya, K. (2017). Penempatan Tenaga Kependidikan: Studi Peran Strategis Kepala Madrasah. Journal of Management in Education, 2(1), 3137.

Sastrohadiwiryo, B. S. (2002). Manajemen Tenaga Kerja Indonesia. Jakarta: Bumi Aksara.

Sirait, J. T. (2006). Memahami Aspek-Aspek Pengelolaan Sumber Daya Manusia Dalam Organisasi. Jakarta: Grasindo.

Soetjipto, B. W. (2008). Kisah Sukses Para Kampium SDM. Jakarta: Salemba Empat.

Tama, I. P. \& Hardiningtyas, D. (2017). Psikologi Industri dalam Perspektif Sistem Industri. Malang: UB Press.

Zebua, R. S. Y., Ihsan, M., \& Nurjanah, N. (2020). Perkembangan Pendidikan Islam Periode Khulafāur Rāsyidīn dan Implikasinya Terhadap Pengembangan Pendidikan Islam di Indonesia. Jurnal Pendidikan Islam Indonesia, 5(1), 115126. https://doi.org/10.35316/jpii.v5i1.228 